\title{
Review
}

Blood Purif 2019;48:203-214

Received: January 9, 2019

DOI: $10.1159 / 000500015$

Accepted: March 29, 2019

Published online: May 16, 2019

\section{Rationale of Hemoadsorption during Extracorporeal Membrane Oxygenation Support}

\author{
L. Christian Nappa ${ }^{\text {a }}$ Stephan Ziegeler ${ }^{b}$ Detlef Kindgen-Milles ${ }^{c}$ \\ a Department of Cardiology and Angiology, Cardiac Arrest Center, Advanced Heart Failure Unit, Hannover Medical \\ School, Hannover, Germany; ${ }^{\text {b }}$ Department of Anesthesiology, Operative Intensive Care Medicine, Pain Management \\ and Emergency Medicine, Hospital Ibbenbüren, Ibbenbüren, Germany; ' Department of Anesthesiology, University \\ Hospital Düsseldorf, Heinrich-Heine University Düsseldorf, Düsseldorf, Germany
}

\section{Keywords}

Inflammation · Systemic inflammatory response syndrome · Cardiogenic shock · Resuscitation - Extracorporeal membrane oxygenation - Extracorporeal life support . Intoxication · Cytokines · Hemoadsorption · Cytosorb

\begin{abstract}
Extracorporeal membrane oxygenation (ECMO) and extracorporeal life support are increasingly used for treating various forms of shock, lung failure, protected interventions and life support including resuscitation. Most patients on ECMO are affected by a systemic inflammatory response caused by the underlying disease as well as the ECMO support itself, which contributes to vasoplegia, multi-organ failure, deterioration and death. Unfortunately, effective strategies for control of inflammation and related organ failure and shock
\end{abstract}

\begin{tabular}{ll}
\hline KARGER & $\begin{array}{l}\text { () } 2019 \text { The Author(s) } \\
\text { Published by S. Karger AG, Basel }\end{array}$ \\
E-Mail karger@karger.com & $\begin{array}{l}\text { This article is licensed under the Creative Commons Attribution- } \\
\text { NonCommercial-NoDerivatives 4.0 International License (CC BY- } \\
\text { www.karger.com/bpu }\end{array}$ \\
& $\begin{array}{l}\text { NC-ND) (http://www.karger.com/Services/OpenAccessLicense). } \\
\text { Usage and distribution for commercial purposes as well as any dis- } \\
\text { tribution of modified material requires written permission. }\end{array}$
\end{tabular}

on ECMO are lacking. Recently, a new polystyrene-based device for hemoadsorption, which aims to reduce excessive levels of inflammatory molecules such as interleukins, cytokines as well as damage- and pathogen-associated molecular patterns, has become available. Here we summarize the rationale, available data and technical aspects of polystyrene-based hemoadsorption during ECMO support, and give recommendations based on existing experience.

$$
\begin{aligned}
& \text { (c) } 2019 \text { The Author(s) } \\
& \text { Published by S. Karger AG, Basel }
\end{aligned}
$$

\section{Background}

The use of extracorporeal membrane oxygenation (ECMO) for mechanical support during severe acute heart failure, lung failure and shock has increased considerably in the last decade [1]. This increase has been en- 
abled by profound technical advances, the recent rise of extracorporeal cardiopulmonary resuscitation (ECPR), and the downgrading of the use of intra-aortic balloon pumps in current guidelines [2]. Today ECMO is used in many previously lethal acute conditions [3-5], and thus morbidity in ECMO patients is very high. Furthermore, ECMO has successfully been used in planned complex procedures such as ultraprotective single-lung ventilation during surgery, or after bilateral lung transplantation [6-9]. Recently, the introduction of a third cannula into standard ECMO circuits has further expanded the options for mechanical support $[5,10]$. However, although ECMO is increasingly used and many major advances in mechanical circulatory support and critical care medicine have been made, morbidity and mortality rates of patients on ECMO still remain unacceptably high.

Conditions potentially requiring ECMO support, such as acute respiratory distress syndrome (ARDS), cardiogenic shock, cardiac arrest, hypothermia and trauma are very heterogenous in nature. Nonetheless, a central common pathogenetic mechanism of clinical deterioration in all of these critical disease states is hyperinflammation $[11,12]$. Although the degree of inflammation differs between conditions, its presence is associated with shared common phenotypes such as vasoplegia, shock and end organ dysfunction. Importantly, this systemic inflammatory response, which occurs to various levels in most patients on ECMO support, is commonly not driven by infection, but is a response to tissue injury associated with the underlying condition. Moreover, the ECMO support itself can induce [13] and maintain an inflammatory response through various mechanisms (Table 1). This response is mainly caused by exposure of blood cells and molecules to the artificial surfaces of tubings, rotor and oxygenator of the ECMO circuit [14] but may also be caused by the release of preformed cytokines from mast cells [15]. The former is especially relevant in children, as the extracorporeal blood volume exposed to foreign surfaces often exceeds the total blood volume of the pediatric patient [16]. Common therapeutic approaches to shock and vasoplegia such as fluid resuscitation and vasopressor administration do not reduce but often further aggravate tissue hypoxia as well as systemic inflammation, and are associated with increased mortality [17-19]. For that reason, US guidelines recommend considering mechanical circulatory support rather than high-dose catecholamine administration [20].

Taken together, the clinical need for interventions targeting inflammation is obvious. Unfortunately, all strategies that aim to control the systemic inflammatory re-
Table 1. Inflammatory triggers during ECMO support

\section{Cellular activation}

Fibrinolysis

Complement activation

Secondary von-Willebrand syndrome

Surfaces of tubings and rotor/oxygenator

Hemolysis

VA-ECMO: retrograde blood flow

Endorgan hyperperfusion/hyperoxygenation

Laminar non-pulsatile flow

For further information [13-15].

ECMO, extracorporeal membrane oxygenation; VA-ECMO, veno-arterial extracorporeal membrane oxygenation.

sponse by direct or indirect means such as steroids [21], plasma exchange [22], toll like receptor antagonists [23], nitric oxide-synthase inhibitors [24] or scavenger haemoglobin derivates [25] have shown conflicting results or failed, or were too specific for widespread use [26]. In this context, extracorporeal hemoadsorption has emerged as a promising novel therapeutic principle. In general, the term hemoadsorption describes extracorporeal adsorption of substances from the blood being pumped through an adsorption device. Several adsorption mechanisms exist, such as adsorption to polymeric beads, as well as adsorption using antibodies or molecules specifically binding to target substances. In this, hemoadsorption is essentially different from allotherblood purification procedures such as dialysis or filtration. Several hemoadsorption devices have been developed, some of which are approved for clinical use.

Here we give an overview on hemoadsorption for use in ECMO-supported patients, with a special focus on the novel polystyrene-based CytoSorb ${ }^{\circledR}$ adsorption device, which in many aspects differs from other hemoadsorption devices. We summarize technical aspects and potential indications of CytoSorb ${ }^{\circledR}$ use in patients on ECMO support and give recommendations from experienced users of this novel therapeutic intervention.

\section{Methods of Hemoadsorption}

At present, several devices using different mechanisms for hemoadsorption of inflammatory mediators have been developed and are currently being investigated. Three of those devices are designed to adsorb endotoxin by immobilized Polymyxin B (Toraymyxin ${ }^{\circledR}$ ), 

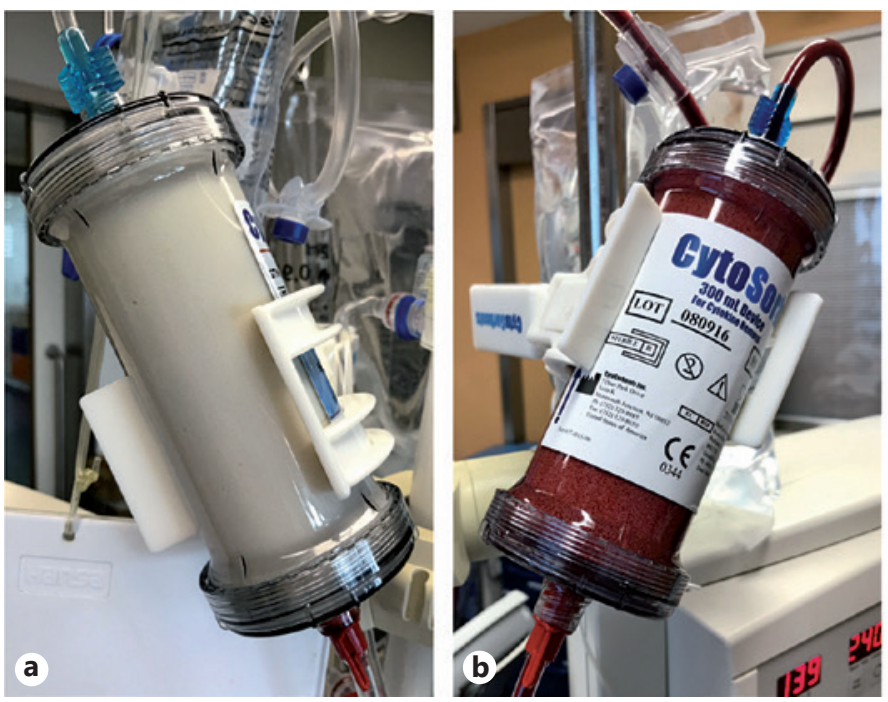

Fig. 1. CytoSorb ${ }^{\circledR}$ before, during and after use. a After priming with saline before connecting to the patient. b During adsorption. c After use in a patient with hyperinflammation, (d) after use in a

polyarginine $\left(\right.$ Alteco $\left.^{\circledR}\right)$, or albumin $\left(\right.$ Matisse ${ }^{\circledR}$ ). Of note, the majority of acute conditions requiring ECMO are not driven by endotoxin, and lipopolysaccharide removal is only meaningful in gram-negative sepsis, since endotoxin does not play a role during the initial phase of grampositive infections. Therefore, these devices do not appear to be meaningful in most patients on ECMO support.

Another approach (Coupled Plasma Filtration Adsorption, Lynda ${ }^{\circledR} /$ Amplia $\left.^{\circledR}\right)$ combines nonspecific adsorption of cytokines and other inflammatory mediators by a resin cartridge (Bellco, Mirandola, Italy) with hemofiltration, notably without adsorbing endotoxin. Although initial results were promising, the prospective COMbining Plasmafiltration and Adsorption Clinical Trial 2 was prematurely stopped because of higher mortality in the treatment arm, which resulted in a device recall [27].

The OXiris ${ }^{\circledR}$ device (Baxter, Vienna, Austria) uses a special membrane (acrylonitrile and sodium methallyl sulfonate copolymer with polyethyleneimine and heparin), and adsorbs a broad spectrum of inflammatory mediators including endotoxin and cytokines. While initial experiences showed a non-significant trend towards reduced vasopressor doses and SOFA scores [28, 29], clinical experience with OXiris remains limited compared to other devices.

PentraSorb $^{\circledR}$ (Pentracor, Hennigsdorf, Germany) is an adsorption device that received a CE mark in 2014. It is
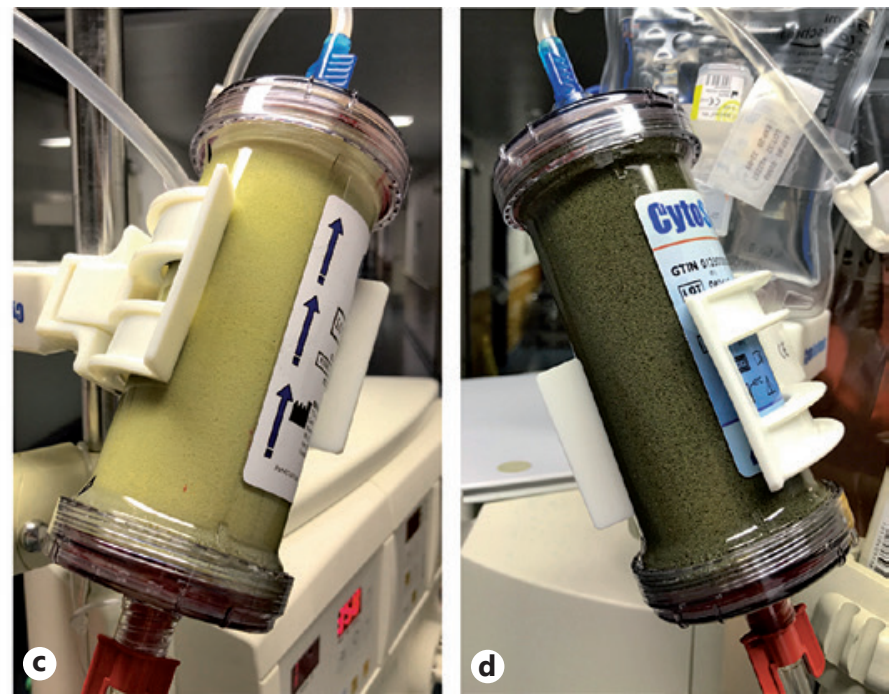

patient with hyperinflammation, rhabdomyolysis and hemolysis. Pictures $\mathbf{a}, \mathbf{c}$ and $\mathbf{d}$ were taken after flushing the adsorber with saline.

filled with agarose beads, which are coated with phosphocholine with the intention of absorbing C-reactive protein [30]. In animal studies, PentraSorb lowers C-reactive protein levels, but in humans the device has not yet been used to a relevant extent outside of clinical trials. Several studies in conditions such as acute myocardial infarction, stroke, inflammatory bowel disease and post-surgery inflammatory response syndrome are currently ongoing. However, none of these studies are completed yet.

\section{CytoSorb $^{\circledR}$}

CytoSorb $^{\circledR}$ (Cytosorbents Inc., Monmouth Junction, NJ, USA) is a CE-certified medical device [31] approved in Europe for use in clinical conditions with elevated blood levels of inflammatory mediators [32]. Very recently, CytoSorb ${ }^{\circledR}$ was further approved for use in hyperbilirubinemia and myoglobinemia [32]. The adsorber (Fig. 1a) consists of a $300 \mathrm{~mL}$ cartridge pre-filled with a sterile isotonic sodium chloride solution and highly biocompatible porous polymer beads with a mean diameter of $450 \mu \mathrm{m}$ each. The resulting active adsorption surface area is extremely large $\left(>45,000 \mathrm{~m}^{2}\right.$ per adsorber) [33]. This enables a highly effective capture of molecules, which are irreversibly bound to the beads by physicochemical interactions, and thus removed from the blood stream. The blood volume inside the adsorber is about $150 \mathrm{~mL}$. The adsorber is approved for blood flow rates between 100 and $700 \mathrm{~mL} / \mathrm{min}$, while a blood flow of at least $150 \mathrm{~mL} / \mathrm{min}$ is recommended [32]. Figure 1 shows 
the CytoSorb ${ }^{\circledR}$ adsorber before (Fig. 1a), during (Fig. 1b) and after (Fig. 1c, d) use.

Binding to the beads is non-specific and includes water-insoluble molecules of small and medium weight (up to around $55 \mathrm{kDa}$ ), a size range which covers most proinflammatory mediators. CytoSorb ${ }^{\circledR}$ adsorbs a broad spectrum of substances and mediators [34] from the blood stream (adsorption spectrum B1042R03EN2017, CytoSorbents Inc.), including pro- and anti-inflammatory mediators as well as pathogen- and damage-associated molecular patterns (PAMPs, DAMPs), myoglobin, bile acids and bilirubin [35]. Water-soluble molecules typically pass through the device without being adsorbed. Removal of substances is concentration-dependent: while high plasma levels of molecules are effectively reduced, low plasma levels are reduced to a much lesser extent [3638]. This intrinsic "autoregulation" makes the complete removal of substances in vivo unlikely. The device also adsorbs several drugs $[34,39,40]$, and in vivo data on drug adsorption is still limited. However, the available data on tested drugs indicates that levels do not fall below the therapeutic range $[40,41]$. In addition, with the experience worldwide of more than 50,000 applications of the device to date, there is at least no signal that drug removal by CytoSorb ${ }^{\circledR}$ therapy translates into adverse events.

In turn, many reports show effective application of CytoSorb $^{\circledR}$ in intoxication, that is, extraordinarily high substance levels, for example, with ticagrelor, amitriptyline, diazepam, digoxin, quetiapine, rivaroxaban and venlafaxine [5, 41-45]. Most importantly, coagulation factors and albumin were not removed by the adsorber to a relevant extent $[46,47]$. Thus, effects on coagulation are rather secondary effects, for example, due to the control of the inflammatory response, or the underlying disease.

From a pathophysiological point of view, the adsorption spectrum of CytoSorb ${ }^{\circledR}$, including PAMPs, DAMPs, inflammatory mediators, myoglobin and bilirubin makes the adsorber very attractive in many patients on ECMO support. This, and the ease of use in ECMO circuits, has already resulted in high frequency use in many centres. Therefore, we focus here on the CytoSorb ${ }^{\circledR}$ adsorption device in patients on ECMO support.

\section{Cytosorb $^{\circledR}$ : Current Evidence}

As of October 2018, more than 50,000 adsorbers have been used worldwide [48]. A rapidly growing number [49] of published cases and case series (Table 2) as well as
Table 2. Potential indications for use of Cytosorb ${ }^{\circledR}$ on ECMO

\begin{tabular}{ll}
\hline Indication & $\begin{array}{l}\text { Reference for } \\
\text { Cytosorb }{ }^{\circledR} \text { use }\end{array}$ \\
\hline Sepsis/septic shock & {$[54,62,63,77-83]$} \\
Endocarditis & {$[56,58]$} \\
Cardiogenic shock & {$[53-56,84]$} \\
ECPR & {$[5]$} \\
Post-cardiac arrest syndrome & {$[5]$} \\
Pre-operative conditioning before cardiac & \\
$\quad$ or thoracic surgery & {$[55,84]$} \\
Post-heart transplant failure & {$[85]$} \\
Post-cardiotomy cardiogenic shock & {$[56]$} \\
Bleeding or urgent surgery in patients & {$[42,44,45]$} \\
$\quad$ on NOAC & {$[54,57,58,86-88]$} \\
ARDS & {$[5,43,44]$} \\
Intoxication & \\
Scorpion envenomation & {$[89]$} \\
Snake bite & {$[60,88,90,91]$} \\
Rhabdomyolysis & \\
Tumour lysis syndrome & {$[82]$} \\
(Poly-)Trauma & {$[92-95]$} \\
Hemophagocytic lympho-histiocytosis & {$[93,96-100]$} \\
Liver failure & {$[101-103]$} \\
Burn injury & {$[104]$} \\
Necrotizing fasciitis & {$[105]$} \\
Pancreatitis & \\
\hline &
\end{tabular}

ARDS, acute respiratory distress syndrome; ECMO, extracorporeal membrane oxygenation; ECPR, extracorporeal resuscitation; NOAC, non-vitamin K oral anticoagulants.

communications at national and international conferences and user meetings suggest promising efficacy and safety of hemoadsorption with CytoSorb ${ }^{\circledR}$. Nonetheless, many observed effects still await confirmation in controlled clinical studies, which are currently in progress. Therefore, at the moment, international guidelines do not recommend hemoadsorption with CytoSorb ${ }^{\circledR}$. The available evidence for CytoSorb $^{\circledR}$ in patients without ECMO is described elsewhere [50]. In addition to ongoing randomized studies, the international CytoSorb ${ }^{\circledR}$ registry [51] is a milestone for generating real-world evidence across very different indications.

Beneficial effects of hemoadsorption in patients on ECMO support include improvements in hemodynamics, reduction in catecholamine demand, decreased capillary leakage, and stabilization of metabolic parameters [52]. Typical examples are as outlined: A 39-year-old patient with pre-existing heart failure developed ARDS and mixed cardiogenic-septic shock. After veno-arterial ECMO (VA-ECMO) implantation and continuous renal 
replacement therapy (CRRT), emergent left ventricular assist device surgery was performed in this still very unstable patient. Hemoadsorption resulted in a notable reduction of inflammatory parameters accompanied by a rapid reduction in vasopressor demand. The clinical course was favourable [53]. Rapid hemodynamic stabilization was also reported in a 33-year-old patient with severe sepsis-related cardiogenic shock and ARDS caused by Staphylococcus aureus and H1N1 pneumonia. As she was still unstable on dobutamine, norepinephrine and vasopressin, she received a combination of VA-ECMO and hemoadsorption, which resulted in rapid stabilization and finally recovery [54]. In a 65-year-old patient with post-infarction ventricular septal rupture and refractory cardiogenic shock with multiple organ failure on 3 catecholamines, combined treatment with VA-ECMO and CytoSorb ${ }^{\circledR}$ resulted in hemodynamic stabilization associated with a significant reduction in vasopressors and normalization of metabolic parameters. The patient underwent cardiac surgery, and ECMO weaning was successful, although the patient later died from fungal sepsis [55]. A 46-year-old patient with progressive infective endocarditis and septic shock underwent valve surgery, but weaning off bypass was unsuccessful due to post-cardiotomy cardiogenic shock (PCCS). After initial stabilization on VA-ECMO the patient's status dramatically deteriorated due to secondary septic shock, and 3 different catecholamines had to be given. CytoSorb ${ }^{\circledR}$ implementation directly into the ECMO circuit was associated with shock control and weaning off catecholamines and ECMO. However, later the patient again developed septic shock and finally died [56].

The effects of CytoSorb ${ }^{\circledR}$ treatment might have several underlying mechanisms, and further mechanistic studies are needed to clarify the exact role and benefits of hemoadsorption in specific conditions. However, several very different diseases share common pathways once deterioration occurs, such as capillary leakage, impaired vascular barrier function and vasoplegia, all of which are associated with inflammation. In this context, CytoSorb ${ }^{\circledR}$ treatment appears to result in improved endothelial integrity, as demonstrated by exposing endothelial cells to serum from a septic patient before and after hemoadsorption [57]. Consistently, reduced leakage is a frequent observation in patients with shock and repeated CytoSorb ${ }^{\circledR}$ treatment [58]. In 2 patients with intoxication and associated shock, combined VA-ECMO and CytoSorb ${ }^{\circledR}$ were associated with rapid clinical improvement and finally recovery $[5,43]$, which emphasizes the potential of CytoSorb ${ }^{\circledR}$ to remove excessive doses of several substances.

Rationale of Extracorporeal

Hemoadsorption during ECMO Support

\section{Indications for CytoSorb ${ }^{\circledR}$ Treatment}

CytoSorb ${ }^{\circledR}$ is an adjunctive therapy approved for conditions with systemic hyperinflammation, increased levels of bilirubin and/or myoglobin. In critical care, most inflammatory states are associated with progressive clinical deterioration. CytoSorb ${ }^{\circledR}$ can thus be considered when hyperinflammation is present, and high, or increasing doses of catecholamines, despite guideline-based treatment including volume resuscitation, are necessary or even ineffective. However, cytokine adsorption might already be useful in specific conditions where deterioration predictably and rapidly occurs, that is, in severe acute systemic inflammation but before intractable vasoplegia is present (preemptive use).

Of note, to date there is no rationale to use CytoSorb ${ }^{\circledR}$ in conditions with elevated inflammatory markers, but without any clinical correlates or without an increased risk of deterioration. For example, a patient with bacterial pneumonia and elevated interleukin 6 (IL-6) levels is not an automatic candidate for CytoSorb ${ }^{\circledR}$ treatment, unless complications such as progressive vasopressor demand, shock or ARDS develop. However, once such a patient shows signs of developing shock or requires ECMO support, CytoSorb ${ }^{\circledR}$ treatment may be considered early, before end organ failure is established.

To date, hemoadsorption with CytoSorb ${ }^{\circledR}$ has been successfully performed in a variety of diseases. An overview of potential indications is given in Table 2. Albeit the listed indications are very heterogenous in nature, they share common biological processes during deterioration and shock, which potentially respond to hemoadsorption with CytoSorb ${ }^{\circledR}$. Cut-offs for starting CytoSorb ${ }^{\circledR}$ are proposed in Table 3, although these essentially depend on the indication, and have not been rigorously tested in clinical studies, but are based on personal experience and available retrospective data.

\section{CytoSorb $^{\circledR}$ : Principles of Application}

The CytoSorb ${ }^{\circledR}$ adsorber can be integrated as an "addon" into various extracorporeal circuits including cardiopulmonary bypass, ECMO/extracorporeal life support, intermittent haemodialysis or CRRT. As an alternative, it can also be used in a "standalone" hemoperfusion mode, which is especially useful in patients who are candidates for CytoSorb ${ }^{\circledR}$, but do not yet need renal replacement therapy (RRT) [59] or ECMO support. 
Table 3. Proposed clinical and laboratory* criteria for considering Cytosorb ${ }^{\circledR}$ use

Indication: inflammation

Consistently increased vasopressor requirements $>0.3(0.5) \mu \mathrm{g} / \mathrm{kg} / \mathrm{min}$

Or use of 2 vasopressors

Or additional need of inotropes

IL-6 $>300-500 \mathrm{pg} / \mathrm{mL}$ as a laboratory sign of systemic hyperinflammation**

Metabolic acidosis $(\mathrm{pH}<7.20)$

Poor lactate clearance

Indication: rhabdomyolysis

Consistently increased myoglobin $>10,000 \mathrm{U} / \mathrm{L}$, especially when no additional indication for hemodialysis is present

Indication: hyperbilirubinemia

Consistently increased bilirubin $>200 \mu \mathrm{mol} / \mathrm{L}$

General: if decision is made for Cytosorb ${ }^{\circledR}$, therapy should be started as early as possible

* Cut-offs are based on opinion and existing literature, and have not been prospectively validated in clinical studies.

** Cytokine levels strongly vary between conditions, depending on the clinical picture and disease progression.

IL, interleukin.

Importantly, the decision for or against CytoSorb ${ }^{\circledR}$ should be made independent of the indication and start of CRRT or other extracorporeal therapies. CytoSorb ${ }^{\circledR}$ treatment should be considered complementary and autonomous, since RRT typically removes water-soluble and CytoSorb ${ }^{\circledR}$ water-insoluble substances, respectively. In selected cases, CytoSorb ${ }^{\circledR}$ may even be used with the intention to avoid CRRT, for example, in patients with rhabdomyolysis for preventing myoglobin-associated renal failure [60].

Like most other extracorporeal devices CytoSorb ${ }^{\circledR}$ requires anticoagulation. Anticoagulation should be maintained at the level required for the extracorporeal circulation in which CytoSorb ${ }^{\circledR}$ is integrated. To date heparin, citrate and argatroban have all been successfully used with CytoSorb ${ }^{\circledR}$. For anticoagulation with heparin, ACT values around $160 \mathrm{~s}$ or aPTT values around $60 \mathrm{~s}$ are usually sufficient. Although clotting of the adsorber is very rare, blood flow should not fall below $150 \mathrm{~mL} / \mathrm{min}$, since these rare clotting events occurred in settings with insufficient blood flow through the device [33]. When integrated into a CRRT system with regional citrate anticoagulation, default settings can be used and additional anticoagulation is not necessary [32].

\section{CytoSorb $^{\circledR}$ : Therapeutic Goals}

For the most common indication of hyperinflammation-associated shock, the primary therapeutic goal of CytoSorb $^{\circledR}$ treatment is shock control and reduction in catecholamine dosages, with the intention of preventing or limiting organ failure. In patients with rhabdomyolysis, the therapeutic goal is reduction of myoglobin levels for protecting kidney function [61]. In acute liver failure, such as toxic hepatitis, the main therapeutic goal is the removal of bilirubin, ammonia and other toxic agents such as bile acids.

Therapeutic efficacy should be assessed on the basis of the clinical course (vasopressor requirements, urine output, hemodynamics) as well as laboratory surrogates (lactate clearance, metabolic status including $\mathrm{pH}$, or IL-6 levels if available). If therapy is continued, a new adsorber should be used - the latest after $24 \mathrm{~h}$ to ensure optimal adsorption efficacy [32]. If clinical deterioration occurs during adsorption, an adsorber change may be considered [62], since saturation of the adsorber may have occurred due to high blood levels of target molecules.

\section{Technical Integration of CytoSorb ${ }^{\circledR}$ into the ECMO Circuit}

The CytoSorb ${ }^{\circledR}$ device requires an extracorporeal circuit for pumping blood through the adsorber (hemoperfusion). To date CytoSorb ${ }^{\circledR}$ is most frequently integrated into CRRT circuits, either before or after the hemofilter, depending on the platform used. It is advisable to place the adsorber in the pre-filter position, as the higher extracellular volume before the filter appears advantageous for hemoperfusion. Once CytoSorb ${ }^{\circledR}$ is considered in a patient on ECMO support, it is most meaningful to install the adsorber directly into the circuit. This can easily be accomplished with a dedicated tubing set provided 

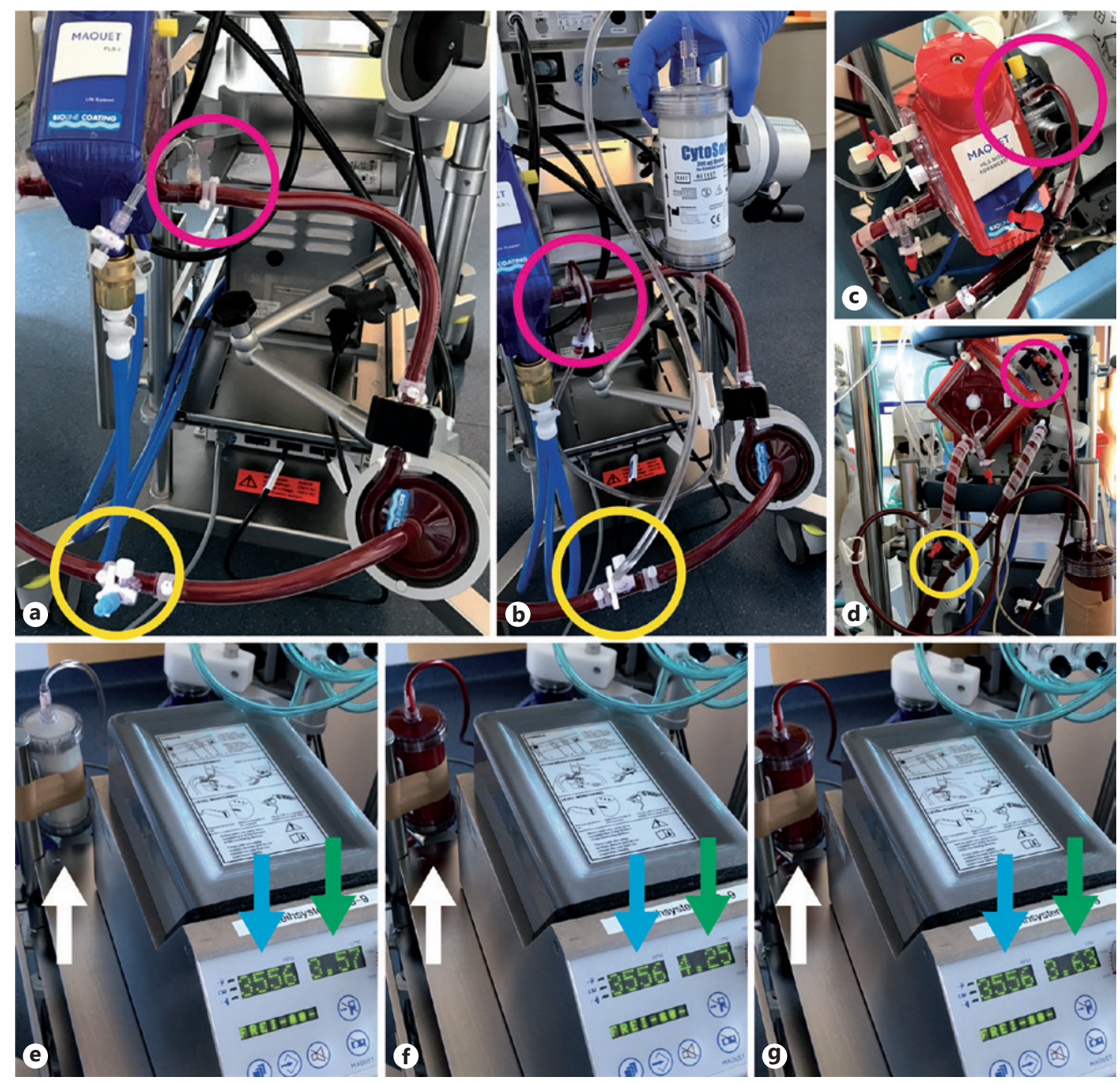

Fig. 2. Connection of CytoSorb ${ }^{\circledR}$ into standard ECMO circuits. a Rotaflow ${ }^{\circledR}$ ECMO circuit with 3-way stopcocks for connection of additional devices before (yellow circle) and after (pink circle) the rotor. $\mathbf{b}$ Connecting the CytoSorb ${ }^{\circledR}$ inlet to the high pressure site (pink circle) and the outlet to the low pressure site (yellow circle) establishes a flow gradient through the adsorber. $\mathbf{c}$ and $\mathbf{d}$ Connec- tion of Cytosorb ${ }^{\circledR}$ into a Cardiohelp ${ }^{\circledR}$ ECMO circuit. e ECMO flow before and after (f) starting blood flow through the CytoSorb ${ }^{\circledR}$ (white arrow), and after manually stopping blood flow again (g). Note the changes in total ECMO flow (green arrow) at unchanged rotor speed (blue arrow), demonstrating the shunt through the parallel CytoSorb ${ }^{\circledR}$ circuit. by the manufacturer, without requirement of additional machines. To ensure an appropriate blood flow, CytoSorb ${ }^{\circledR}$ has to be connected in parallel (not in series) to the circuit: Connection of the inlet to the high pressure site (post-rotor; Fig. 2a) and of the outlet to the low pressure site (pre-rotor; Fig. 2a) with the manufacturers tubing set results in adsorber flow rates of $400-700 \mathrm{~mL} / \mathrm{min}$ with normal ECMO flow rates $(3-5 \mathrm{~L} / \mathrm{min})$. Of note, this configuration establishes a "left-to-right"-shunt in the
ECMO circuit, which increases the total ECMO flow at a given rotor speed (Fig. 2b): A total ECMO flow of $4.7 \mathrm{~L} / \mathrm{min}$ then consists of a $0.6-0.7 \mathrm{~L} / \mathrm{min}$ shunt flow to the CytoSorb ${ }^{\circledR}$ and $4.0-4.1 \mathrm{~L} / \mathrm{min}$ flow to the patient, which has to be considered for clinical management. Compared to serial connection in hemoperfusion or CRRT circuits, the parallel connection of CytoSorb ${ }^{\circledR}$ to the ECMO results in a moderate recirculation volume, that is, blood that has already passed the adsorber enters 
it again after passing the rotor. Although unlikely, it is currently unknown whether this recirculation has clinical relevance in terms of adsorption efficacy.

\section{When Should I Start CytoSorb ${ }^{\circledR}$ and for How Long Should I Get Treated?}

Several reports suggest that early initiation of treatment is beneficial, at best within $24 \mathrm{~h}$ after onset of injury [51, 62, 63]. Of note, providing guideline-based standard therapies for a given condition has absolute priority in clinical management. CytoSorb ${ }^{\circledR}$ treatment should always be considered complementary and adjunctive in this context.

If a patient has not yet received CytoSorb ${ }^{\circledR}$, but there is inadequate response to standard therapy after an observation period of a maximum of $6 \mathrm{~h}$, clinical and laboratory re-evaluation should be performed to consider CytoSorb ${ }^{\circledR}$ treatment. However, in selected cases, it might be reasonable to start CytoSorb ${ }^{\circledR}$ treatment immediately and in parallel to standard therapy, for example, in patients with fulminant septic shock. Moreover, in clinical conditions with severe acute systemic inflammation, which commonly deteriorate into a shock state with vasoplegia, preventive use of CytoSorb ${ }^{\circledR}$ to avoid shock development may be considered. In general, initiation of CytoSorb ${ }^{\circledR}$ therapy later than $48 \mathrm{~h}$ after the onset of systemic hyperinflammation is associated with a lower chance of success [62].

The decision to stop CytoSorb ${ }^{\circledR}$ treatment has to be made on a very individual basis. There are patients who adequately respond to the use of a single adsorber, for example, in intoxication [43] or when oral anticoagulation (e.g., ticagrelor, rivaroxaban) has to be terminated prior to surgery, or in cases of bleeding [42]. However, if the source of systemic inflammation persists, several consecutive adsorbers may be necessary.

CytoSorb ${ }^{\circledR}$ treatment may be discontinued or stopped using different surrogate events:

- If sufficient clinical stabilization has occurred (efficacy)

- If the toxic agent has been reduced to non-toxic levels in the patient (efficacy)

- If the clinical situation has deteriorated to a level that renders further hemoadsorption useless (futility)

\section{Prototypical Scenarios}

In line with the available literature and our personal experience, we hereby propose candidate settings for hemoadsorption with CytoSorb ${ }^{\circledR}$ on ECMO support. Al- beit these candidate settings appear prototypically suitable, there are no prospective randomized controlled trials confirming efficacy of CytoSorb ${ }^{\circledR}$ treatment in this context.

$E C P R$. Due to the still disappointing results from conventional cardiopulmonary resuscitation $(\mathrm{CPR})$ in patients with out-of-hospital cardiac arrest, the use of VAECMO for CPR is rapidly growing [64], especially for younger patients. To date ECMO is usually inserted after arrival at the hospital, but some centres have started to establish preclinical use of ECMO $[65,66]$. ECMO is also the commonly used support device for profound shock after successful CPR. Considering the frequently observed refractory shock after CPR (post-resuscitation syndrome) $[67,68]$, the strong association of inflammation and prognosis in resuscitated patients [11, 69], and the opportunity to intervene very early after onset of injury, ECPR appears to be a good candidate for hemoadsorption.

$A R D S$. In patients with severe ARDS veno-venous ECMO (VV-ECMO) is frequently used to establish lungprotective ventilation [70], although there is some debate on timing and patient selection [71]. In contrast to sepsis, where the start of injury can often not be well determined, the evolution of ARDS is quickly noticed through its symptoms or ventilation parameters. Hyperinflammation is a common phenomenon in ARDS, especially in those who are on ECMO support, but steroids are ineffective and potentially associated with adverse effects [72]. Therefore, a severe or progressive inflammatory state during ARDS on ECMO support appears to be a good setting for hemoadsorption [58], at least in those with vasopressor demand.

Secondary sepsis on ECMO. Clinical stabilization after initiation of ECMO support is commonly observed in the majority of patients across different underlying conditions. While VA-ECMO rapidly and directly improves hemodynamics and end organ perfusion, VV-ECMO enhances gas exchange. However, an indirect effect on hemodynamics and catecholamine demand is observed also in most patients on VV-ECMO, likely resulting from resolution of hypoxemia and acidosis. The duration of ECMO support sometimes needs to be extended even after resolution of the underlying disease due to secondary complications. One such adverse event is secondary sepsis on ECMO [73]. Secondary sepsis may have different foci, but typically results in often rapidly worsening hemodynamics and increased catecholamine demand, all of which are again characterized by systemic inflammation. Therefore, it appears useful to monitor 
sensitive laboratory markers such as IL-6 during ECMO support, which may indicate a developing sepsis early. Hemoadsorption can be considered once a notable increase in these markers and worsening hemodynamics occur, or if sepsis and systemic hyperinflammation are anticipated, such as in cardiac surgery for infective endocarditis $[56,74]$.

PCCS. After urgent as well as elective cardiac surgery a special kind of shock may occur which is known as PCCS. This shock form is not typically driven by infection, but rather by a response of the body to surgical trauma, bleeding and cardiopulmonary bypass. PCCS may already occur in the operating theatre with difficulty in weaning off cardiopulmonary bypass, or early during the postoperative course in the ICU. Despite the use of currently available pharmaceutical and mechanical support strategies for PCCS, which is frequently VAECMO, mortality remains high $[75,76]$. Most cases of PCCS, especially those requiring ECMO, are characterized by a severe systemic inflammatory response and high catecholamine demand. Thus, PCCS on ECMO appears to be a potential candidate for early hemoadsorption use [56].

\section{Conclusions}

Patients on ECMO-/extracorporeal life support frequently encounter a systemic inflammatory response, either associated with the underlying condition, ECMO support or both. CytoSorb ${ }^{\circledR}$ is a novel device for adsorbing inflammatory and other mediators from the circulation. Dedicated tubing sets facilitate rapid and easy implementation into contemporary ECMO and RRT circuits.
To date, promising data from case series, retrospective studies, a multicentre registry and a few prospective trials suggest safety and efficacy of CytoSorb ${ }^{\circledR}$ in different clinical conditions including hyperinflammation or intoxications. Although the device is already used with increasing frequency in various settings, prospective controlled studies are needed to confirm its efficacy in different diseases, and to investigate optimal timing for initiation and duration of use, the relevance of drug removal, and finally, effects on morbidity and mortality.

\section{Acknowledgements}

None.

\section{Disclosure Statement}

L.C.N. received lecture, consulting and proctoring honoraria and travel support from Abiomed, lecture honoraria from Maquet, lecture honoraria from Zoll, and travel support, lecture honoraria and consulting fees from CytoSorbents. D.K.-M. received lecture and consulting honoraria from CytoSorbents and from Fresenius Medical Care. S.Z. received consulting fees and travel support from CytoSorbents.

\section{Funding Source}

There was no funding specifically supporting the present review, which is solely investigator initiated work.

\section{Author Contribution}

All authors contributed equally to writing the article and editing the manuscript.

\section{References}

1 Thiagarajan RR, Barbaro RP, Rycus PT, Mcmullan DM, Conrad SA, Fortenberry JD, et al.; ELSO member centers. Extracorporeal Life Support Organization Registry International Report 2016. ASAIO J. 2017 Jan/Feb; 63(1):60-7.

2 Ponikowski P, Voors AA, Anker SD, Bueno H, Cleland JGF, Coats AJS, et al.; ESC Scientific Document Group. 2016 ESC Guidelines for the diagnosis and treatment of acute and chronic heart failure: The Task Force for the diagnosis and treatment of acute and chronic heart failure of the European Society of Cardiology (ESC) Developed with the special contribution of the Heart Failure Association (HFA) of the ESC. Eur Heart J. 2016 Jul;37(27):2129-200.
3 Napp LC, Kühn C, Bauersachs J. ECMO in cardiac arrest and cardiogenic shock. Herz. 2017 Feb;42(1):27-44.

4 Napp LC, Kühn C, Hoeper MM, VogelClaussen J, Haverich A, Schäfer A, et al. Cannulation strategies for percutaneous extracorporeal membrane oxygenation in adults. Clin Res Cardiol. 2016 Apr;105(4): 283-96.

5 Napp LC, Vogel-Claussen J, Schäfer A, Haverich A, Bauersachs J, Kühn C, et al. First-inMan Fully Percutaneous Complete Bypass of Heart and Lung. JACC Cardiovasc Interv. 2017 Dec;10(24):e231-3.

6 Redwan B, Semik M, Dickgreber N, Ziegeler $\mathrm{S}$, Fischer S. Single site cannulation veno-ve- nous extracorporeal lung support during pulmonary resection in patients with severely compromised pulmonary function. ASAIO J. 2015 May-Jun;61(3):366-9.

7 Redwan B, Ziegeler S, Freermann S, Nique L, Semik M, Lavae-Mokhtari M, et al. Intraoperative veno-venous extracorporeal lung support in thoracic surgery: a single-centre experience. Interact Cardiovasc Thorac Surg. 2015 Dec;21(6):766-72.

8 Redwan B, Ziegeler S, Dickgreber N, Fischer $\mathrm{S}$. Metastasectomy in a lung graft using highflow venovenous extracorporeal lung support in a patient after single lung transplantation. J Thorac Cardiovasc Surg. 2015 Nov;150(5): e79-81.
Rationale of Extracorporeal

Hemoadsorption during ECMO Support 
9 Tudorache I, Sommer W, Kühn C, Wiesner $\mathrm{O}$, Hadem J, Fühner T, et al. Lung transplantation for severe pulmonary hypertensionawake extracorporeal membrane oxygenation for postoperative left ventricular remodelling. Transplantation. 2015 Feb;99(2): 451-8.

10 Napp LC, Bauersachs J. Triple cannulation ECMO. In: Firstenberg M, editor. ECMO, InTech Open. 2016.

11 Bro-Jeppesen J, Kjaergaard J, Wanscher M, Nielsen N, Friberg H, Bjerre M, et al. Systemic Inflammatory Response and Potential Prognostic Implications After Out-of-Hospital Cardiac Arrest: A Substudy of the Target Temperature Management Trial. Crit Care Med. 2015 Jun;43(6):1223-32.

12 Kellum JA, Kong L, Fink MP, Weissfeld LA, Yealy DM, Pinsky MR, et al.; GenIMS Investigators. Understanding the inflammatory cytokine response in pneumonia and sepsis: results of the Genetic and Inflammatory Markers of Sepsis (GenIMS) Study. Arch Intern Med. 2007 Aug;167(15):1655-63.

13 Chen Q, Yu W, Shi J, Shen J, Hu Y, Gao T, et al. The effect of venovenous extra-corporeal membrane oxygenation (ECMO) therapy on immune inflammatory response of cerebral tissues in porcine model. J Cardiothorac Surg. 2013 Aug;8(1): 186.

14 Millar JE, Fanning JP, McDonald CI, McAuley DF, Fraser JF. The inflammatory response to extracorporeal membrane oxygenation (ECMO): a review of the pathophysiology. Crit Care. 2016 Nov;20(1):387.

15 McIlwain RB, Timpa JG, Kurundkar AR, Holt DW, Kelly DR, Hartman YE, et al.; Plasma concentrations of inflammatory cytokines rise rapidly during ECMO-related SIRS due to the release of preformed stores in the intestine. Lab Invest. 2010 Jan;90(1):128-39.

16 Kozik DJ, Tweddell JS. Characterizing the inflammatory response to cardiopulmonary bypass in children. Ann Thorac Surg. 2006 Jun; 81(6):S2347-54.

17 Boyd JH, Forbes J, Nakada TA, Walley KR, Russell JA. Fluid resuscitation in septic shock: a positive fluid balance and elevated central venous pressure are associated with increased mortality. Crit Care Med. 2011 Feb;39(2): 259-65.

18 Dünser MW, Ruokonen E, Pettilä V, Ulmer $\mathrm{H}$, Torgersen C, Schmittinger CA, et al. Association of arterial blood pressure and vasopressor load with septic shock mortality: a post hoc analysis of a multicenter trial. Crit Care. 2009;13(6):R181.

19 Tarvasmäki T, Lassus J, Varpula M, Sionis A, Sund R, Køber L, et al.; CardShock study investigators. Current real-life use of vasopressors and inotropes in cardiogenic shock adrenaline use is associated with excess organ injury and mortality. Crit Care. 2016 Jul; 20(1):208.

20 Rihal CS, Naidu SS, Givertz MM, Szeto WY, Burke JA, Kapur NK, et al.; Society for Cardiovascular Angiography and Interventions
(SCAI), Heart Failure Society of America (HFSA), Society of Thoracic Surgeons (STS), American Heart Association (AHA), and American College of Cardiology (ACC). 2015 SCAI/ACC/HFSA/STS Clinical Expert Consensus Statement on the Use of Percutaneous Mechanical Circulatory Support Devices in Cardiovascular Care: Endorsed by the American Heart Association, the Cardiological Society of India, and Sociedad Latino Americana de Cardiología Intervencionista; Affirmation of Value by the Canadian Association of Interventional Cardiology-Association Canadienne de Cardiologie d'intervention. J Am Coll Cardiol. 2015 May;65(19):2140-1.

21 Venkatesh B, Finfer S, Cohen J, Rajbhandari D, Arabi Y, Bellomo R, et al.; ADRENAL Trial Investigators and the Australian-New Zealand Intensive Care Society Clinical Trials Group. Adjunctive Glucocorticoid Therapy in Patients with Septic Shock. N Engl J Med. 2018 Mar;378(9):797-808.

22 Rimmer E, Houston BL, Kumar A, Abou-Setta AM, Friesen C, Marshall JC, et al. The efficacy and safety of plasma exchange in patients with sepsis and septic shock: a systematic review and meta-analysis. Crit Care. 2014 Dec;18(6):699.

23 Opal SM, Laterre PF, Francois B, LaRosa SP, Angus DC, Mira JP, et al.; ACCESS Study Group. Effect of eritoran, an antagonist of MD2-TLR4, on mortality in patients with severe sepsis: the ACCESS randomized trial. JAMA. 2013 Mar;309(11):1154-62.

24 López A, Lorente JA, Steingrub J, Bakker J, McLuckie A, Willatts S, et al. Multiple-center, randomized, placebo-controlled, doubleblind study of the nitric oxide synthase inhibitor 546C88: effect on survival in patients with septic shock. Crit Care Med. 2004 Jan;32(1): 21-30.

25 Vincent JL, Privalle CT, Singer M, Lorente JA, Boehm E, Meier-Hellmann A, et al. Multicenter, randomized, placebo-controlled phase III study of pyridoxalated hemoglobin polyoxyethylene in distributive shock (PHOENIX). Crit Care Med. 2015 Jan;43(1): 57-64.

26 Ziegler EJ, Fisher CJ Jr, Sprung CL, Straube RC, Sadoff JC, Foulke GE, et al. Treatment of gram-negative bacteremia and septic shock with HA-1A human monoclonal antibody against endotoxin. A randomized, doubleblind, placebo-controlled trial. The HA-1A Sepsis Study Group. N Engl J Med. 1991 Feb; 324(7):429-36.

27 https://www.bfarm.de/SharedDocs/Kundeninfos/DE/07/2018/05117-18_kundeninfo_ de.html (accessed November 8, 2018).

28 Rimmelé T, Assadi A, Cattenoz M, Desebbe O, Lambert C, Boselli E, et al. High-volume haemofiltration with a new haemofiltration membrane having enhanced adsorption properties in septic pigs. Nephrol Dial Transplant. 2009 Feb;24(2):421-7.

29 Shum HP, Chan KC, Kwan MC, Yan WW. Application of endotoxin and cytokine ad- sorption haemofilter in septic acute kidney injury due to Gram-negative bacterial infection. Hong Kong Med J. 2013 Dec;19(6):4917.

30 Slagman AC, Bock C, Abdel-Aty H, Vogt B, Gebauer F, Janelt G, et al. Specific removal of $\mathrm{C}$-reactive protein by apheresis in a porcine cardiac infarction model. Blood Purif. 2011; 31(1-3):9-17.

31 Certificate 3804606 (www.dekra-certification.com).

32 Cytosorbents Inc.: Instructions for use, Document Number 17-0071-14.

33 Cytosorbents Inc.: Internal communication.

34 Poli EC, Rimmelé T, Schneider AG. Hemoadsorption with $\mathrm{CytoSorb}^{\circledR}$. Intensive Care Med. 2019 Feb;45(2):236-9.

35 Gruda MC, Ruggeberg KG, O’Sullivan P, Guliashvili T, Scheirer AR, Golobish TD, et al. Broad adsorption of sepsis-related PAMP and DAMP molecules, mycotoxins, and cytokines from whole blood using CytoSorb ${ }^{\circledR}$ sorbent porous polymer beads. PLoS One. 2018 Jan; 13(1):e0191676.

36 Namas RA, Namas R, Lagoa C, Barclay D, Mi $\mathrm{Q}$, Zamora R, et al. Hemoadsorption reprograms inflammation in experimental gramnegative septic peritonitis: insights from in vivo and in silico studies. Mol Med. 2012 Dec; 18(10):1366-74.

37 Peng ZY, Bishop JV, Wen XY, Elder MM, Zhou F, Chuasuwan A, et al. Modulation of chemokine gradients by apheresis redirects leukocyte trafficking to different compartments during sepsis, studies in a rat model. Crit Care. 2014 Jul;18(4):R141.

38 Peng ZY, Carter MJ, Kellum JA. Effects of hemoadsorption on cytokine removal and short-term survival in septic rats. Crit Care Med. 2008 May;36(5):1573-7.

39 Reiter K, Bordoni V, Dall'Olio G, Ricatti MG, Soli M, Ruperti S, et al. In vitro removal of therapeutic drugs with a novel adsorbent system. Blood Purif. 2002;20(4): 380-8.

40 Zoller M, Döbbeler G, Maier B, Vogeser M, Frey L, Zander J. Can cytokine adsorber treatment affect antibiotic concentrations? A case report. J Antimicrob Chemother. 2015 Jul; 70(7):2169-71.

41 Koertge A, Mitzner S, Wasserkort R. Removal Capability Of Cytosorb Hemadsorption Columns For Selected Prescription Drugs Frequently Related To Drug Overdose. Abstracts from the 44th ESAO and 7th IFAO Congress, 6-9 September 2017, Vienna, Austria. Int J Artif Organs. 2017;40(8):382-428.

42 Angheloiu GO, Gugiu GB, Ruse C, Pandey R, Dasari RR, Whatling C. Ticagrelor Removal From Human Blood. JACC Basic Transl Sci. 2017 Apr;2(2):135-45

43 Schroeder I, Zoller M, Angstwurm M, Kur F, Frey L. Venlafaxine intoxication with development of takotsubo cardiomyopathy: successful use of extracorporeal life support, intravenous lipid emulsion and CytoSorb ${ }^{\circledR}$. Int J Artif Organs. 2017 Jul;40(7):358-60. 
44 Koertge A, Wasserkort R, Wild T, Mitzner S. Extracorporeal Hemoperfusion as a Potential Therapeutic Option for Critical Accumulation of Rivaroxaban. Blood Purif. 2018;45(13):126-8.

45 Angheloiu GO, Ryn J, Goss AM. Removal of Dabigatran Using Sorbent Hemadsorption. Circulation. 2015 Nov; 132(Suppl 3):A12901.

46 Harm S, Falkenhagen D, Hartmann J. Pore size-a key property for selective toxin removal in blood purification. Int J Artif Organs. 2014 Sep;37(9):668-78.

47 Poli E, Alberio L, Bauer-Doerries A, Marcucci C, Roumy A, Kirsch M, et al. Effect of cytoadsorbant device on coagulation factors during cardio-pulmonary bypass (abstract, 38th International Symposium on Intensive Care and Emergency Medicine). Critical Care 2018:22:82:P416.

48 Cytosorbents Inc.: Personal Communication

49 https://literature.cytosorb-therapy.com/ (accessed December 5, 2018)

50 Bonavia A, Groff A, Karamchandani K, Singbartl K. Clinical Utility of Extracorporeal Cytokine Hemoadsorption Therapy: A Literature Review. Blood Purif. 2018;46(4):337-49.

51 Friesecke S, Träger K, Schittek GA, Molnar Z, Bach F, Kogelmann K, et al. International registry on the use of the CytoSorb ${ }^{\circledR}$ adsorber in ICU patients: study protocol and preliminary results. Med Klin Intensivmed Notf Med. 2017, Epub ahead of print.

52 Datzmann T, Träger K. Extracorporeal membrane oxygenation and cytokine adsorption. J Thorac Dis. 2018 Mar;10(S5 Suppl 5):S653-60.

53 Bruenger F, Kizner L, Weile J, Morshuis M, Gummert JF. First successful combination of ECMO with cytokine removal therapy in cardiogenic septic shock: a case report. Int J Artif Organs. 2015 Feb;38(2):113-6.

54 Lees NJ, Rosenberg A, Hurtado-Doce AI, Jones J, Marczin N, Zeriouh M, et al. Combination of ECMO and cytokine adsorption therapy for severe sepsis with cardiogenic shock and ARDS due to Panton-Valentine leukocidin-positive Staphylococcus aureus pneumonia and H1N1. J Artif Organs. 2016 Dec;19(4):399-402.

55 Marek S, Gamper G, Reining G, Bergmann P, Mayr H, Kliegel A. ECMO and cytokine removal for bridging to surgery in a patient with ischemic ventricular septal defect - a case report. Int J Artif Organs. 2017 Sep;40(9):526-9.

56 Nemeth E, Szigeti S, Varga T, Daroczi L, Barati Z, Merkely B, et al. Continuous cytokine haemoadsorption incorporated into a venoarterial ECMO circuit for the management of postcardiotomy cardiogenic and septic shock - a case report. Perfusion. 2018 Oct;33(7):593-6.

57 David S, Thamm K, Schmidt BM, Falk CS, Kielstein JT. Effect of extracorporeal cytokine removal on vascular barrier function in a septic shock patient. J Intensive Care. 2017 Jan 5(1):12.

58 Träger K, Schütz C, Fischer G, Schröder J, Skrabal C, Liebold A, et al. Cytokine Reduction in the Setting of an ARDS-Associated Inflam- matory Response with Multiple Organ Failure. Case Rep Crit Care. 2016;2016:9852073.

59 Hawchar F, László I, Öveges N, Trásy D, Ondrik Z, Molnar Z. Extracorporeal cytokine adsorption in septic shock: A proof of concept randomized, controlled pilot study. J Crit Care. 2019 Feb;49:172-8.

60 Wiegele M, Krenn CG. Cytosorb ${ }^{\mathrm{TM}}$ in a patient with Legionella pneumonia-associated rhabdomyolysis: a case report. ASAIO J. 2015 May-Jun;61(3):e14-6.

61 Holt S, Moore K. Pathogenesis of renal failure in rhabdomyolysis: the role of myoglobin. Exp Nephrol. 2000 Mar-Apr;8(2):72-6

62 Kogelmann K, Jarczak D, Scheller M, Drüner M. Hemoadsorption by CytoSorb in septic patients: a case series. Crit Care. 2017 Mar; 21(1):74.

63 Friesecke S, Stecher SS, Gross S, Felix SB, Nierhaus A. Extracorporeal cytokine elimination as rescue therapy in refractory septic shock: a prospective single-center study. J Artif Organs. 2017 Sep;20(3):252-9.

64 Fagnoul D, Combes A, De Backer D. Extracorporeal cardiopulmonary resuscitation. Curr Opin Crit Care. 2014 Jun;20(3):259-65.

65 Lamhaut L, Hutin A, Deutsch J, Raphalen JH, Jouffroy R, Orsini JP, et al. Extracorporeal Cardiopulmonary Resuscitation (ECPR) in the Prehospital Setting: An Illustrative Case of ECPR Performed in the Louvre Museum. Prehosp Emerg Care. 2017 May-Jun;21(3): 386-9.

66 Lamhaut L, Jouffroy R, Soldan M, Phillipe P, Deluze T, Jaffry M, et al. Safety and feasibility of prehospital extra corporeal life support implementation by non-surgeons for out-ofhospital refractory cardiac arrest. Resuscitation. 2013 Nov;84(11):1525-9.

67 Negovsky VA. The second step in resuscitation-the treatment of the 'post-resuscitation disease'. Resuscitation. 1972 Mar;1(1):1-7.

68 Nolan JP, Neumar RW, Adrie C, Aibiki M, Berg RA, Böttiger BW, et al. Post-cardiac arrest syndrome: epidemiology, pathophysiology, treatment, and prognostication. A Scientific Statement from the International Liaison Committee on Resuscitation; the American Heart Association Emergency Cardiovascular Care Committee; the Council on Cardiovascular Surgery and Anesthesia; the Council on Cardiopulmonary, Perioperative, and Critical Care; the Council on Clinical Cardiology; the Council on Stroke. Resuscitation. 2008 Dec; 79(3):350-79.

69 Vaahersalo J, Skrifvars MB, Pulkki K, Stridsberg M, Røsiø H, Hovilehto S, et al.; FINNRESUSCI Laboratory Study Group. Admission interleukin-6 is associated with post resuscitation organ dysfunction and predicts longterm neurological outcome after out-of-hospital ventricular fibrillation. Resuscitation. 2014 Nov;85(11):1573-9.

70 Abrams D, Brodie D. Extracorporeal Membrane Oxygenation Is First-Line Therapy for Acute Respiratory Distress Syndrome. Crit Care Med. 2017 Dec;45(12):2070-3.
71 Stephens RS, Brower RG. Extracorporeal Membrane Oxygenation Is Not First-Line Therapy for the Acute Respiratory Distress Syndrome. Crit Care Med. 2017 Dec;45(12): 2074-7.

72 Takaki M, Ichikado K, Kawamura K, Gushima Y, Suga M. The negative effect of initial high-dose methylprednisolone and tapering regimen for acute respiratory distress syndrome: a retrospective propensity matched cohort study. Crit Care. 2017 Jun;21(1):135.

73 Meyer DM, Jessen ME, Eberhart RC; Extracorporeal Life Support Organization. Neonatal extracorporeal membrane oxygenation complicated by sepsis. Ann Thorac Surg. 1995 Apr;59(4):975-80.

74 Träger K, Skrabal C, Fischer G, Datzmann T, Schroeder J, Fritzler D, et al. Hemoadsorption treatment of patients with acute infective endocarditis during surgery with cardiopulmonary bypass - a case series. Int J Artif Organs. 2017 May;40(5):240-9.

75 Wang L, Wang H, Hou X. Clinical Outcomes of Adult Patients Who Receive Extracorporeal Membrane Oxygenation for Postcardiotomy Cardiogenic Shock: A Systematic Review and Meta-Analysis. J Cardiothorac Vasc Anesth. 2018 Oct;32(5):2087-93.

76 Rastan AJ, Dege A, Mohr M, Doll N, Falk V, Walther T, et al. Early and late outcomes of 517 consecutive adult patients treated with extracorporeal membrane oxygenation for refractory postcardiotomy cardiogenic shock. J Thorac Cardiovasc Surg 2010 Feb;139(2): 302-11, 311.e1.

77 Leonardis F, De Angelis V, Frisardi F, Pietrafitta C, Riva I, Valetti TM, et al. Effect of Hemoadsorption for Cytokine Removal in Pneumococcal and Meningococcal Sepsis. Case Rep Crit Care. 2018 Jun;2018: 1205613.

78 Hinz B, Jauch O, Noky T, Friesecke S, Abel P, Kaiser R. CytoSorb, a novel therapeutic approach for patients with septic shock: a case report. Int J Artif Organs. 2015 Aug;38(8):461-4.

79 Mitzner SR, Gloger M, Henschel J, Koball S. Improvement of hemodynamic and inflammatory parameters by combined hemoadsorption and hemodiafiltration in septic shock: a case report. Blood Purif. 2013;35(4): 314-5.

80 Hetz H, Berger R, Recknagel P, Steltzer H. Septic shock secondary to $\beta$-hemolytic streptococcus-induced necrotizing fasciitis treated with a novel cytokine adsorption therapy. Int J Artif Organs. 2014 May;37(5): 422-6.

81 Morris C, Gray L, Giovannelli M. Early report: The use of Cytosorb ${ }^{\mathrm{TM}}$ haemabsorption column as an adjunct in managing severe sepsis: initial experiences, review and recommendations. J Intensive Care Soc. 2015 Aug; 16(3):257-64.

82 Steltzer H, Grieb A, Mostafa K, Berger R. Use of CytoSorb in Traumatic Amputation of the Forearm and Severe Septic Shock. Case Rep Crit Care. 2017;2017:8747616. 
83 Withanage RK, Wijesuriya N. Cytokine Adsorption in Septic Shock and Multiorgan Failure Following Major Obstetric Hemorrhage. J Case Reports. 2017;7:124-6.

84 Dogan G, Hanke J, Puntigam J, Haverich A, Schmitto JD. Hemoadsorption in cardiac shock with bi ventricular failure and giant-cell myocarditis: A case report. Int J Artif Organs. 2018 Aug;41(8):474-9.

85 Nemeth E, Kovacs E, Racz K, Soltesz A, Szigeti S, Kiss N, et al. Impact of intraoperative cytokine adsorption on outcome of patients undergoing orthotopic heart transplantation-an observational study. Clin Transplant. 2018 Apr;32(4):e13211.

86 Khan ZA. A Clinical Experience Of Using Extracorporeal Cytokine Adsorption Device $\left(\right.$ Cytosorb $^{\circledR}$ ) In A Case Of Dengue Fever. J Evid Based Med Healthc. 2016;3(87):477981.

87 Schädler D, Pausch C, Heise D, Meier-Hellmann A, Brederlau J, Weiler N, et al. The effect of a novel extracorporeal cytokine hemoadsorption device on IL-6 elimination in septic patients: A randomized controlled trial. PLoS One. 2017 Oct;12(10):e0187015.

88 Suefke S, Sayk F, Nitschke M. Hemoadsorption in Infection-Associated Rhabdomyolysis. Ther Apher Dial. 2016 Oct;20(5):531-3.

89 Paul R, Jha BK, Shetty VK. A case of viper snake bite presenting with gangrene and sepsis associated multiorgan failure, successfully treated with Cytosorb ${ }^{\circledR}$ as an adjunct therapya clinical experience. J Evid Based Med Healthc. 2018;5(6):559-61.

90 Kousoulas L, Wittel U, Fichtner-Feigl S, Utzolino S. Hemoadsorption in a Case of Severe Septic Shock and Necrotizing Fasciitis Caused by Nontraumatic Renal Rupture due to Pyelonephritis with Obstructive Uropathy. Case Rep Crit Care. 2018 Apr;2018:5248901.
91 Kuntsevich VI, Feinfeld DA, Audia PF, Young W, Capponi V, Markella M, et al. In-vitro myoglobin clearance by a novel sorbent system. Artif Cells Blood Substit Immobil Biotechnol. 2009;37(1):45-7.

92 Frimmel S, Bogdanow S, Schipper J, Hinz M, Mitzner S, Koball S. Cytokine Adsorption Is A Promising Tool For Therapy Of Hemophagocytic Lymphohistiocytosis (HLH). Nephrol Dial Transplant. 2017;32(suppl 3):iii189.

93 Frimmel S, Schipper J, Henschel J, Yu TT, Mitzner SR, Koball S. First description of single-pass albumin dialysis combined with cytokine adsorption in fulminant liver failure and hemophagocytic syndrome resulting from generalized herpes simplex virus 1 infection. Liver Transpl. 2014 Dec;20(12):1523-4.

94 Greil C, Roether F, La Rosée P, Grimbacher B, Duerschmied D, Warnatz K. Rescue of Cytokine Storm Due to HLH by Hemoadsorption in a CTLA4-Deficient Patient. J Clin Immunol. 2017 Apr;37(3):273-6.

95 Milella L, Ficarella M: First Application of CVVHDF, Plasmapheresis and "Cytosorb Absorber" to Solve a Pediatric Haemophagocitic Histyocitosis Case. Res Pediatr Neonatol 2017;1:RPN.000510.

96 Büttner S, Patyna S, Koch B, Finkelmeier F, Geiger H, Sarrazin C, et al. Application of Hemoadsorption in a Case of Liver Cirrhosis and Alcohol-Related Steatohepatitis with Preexisting Hepatitis C Infection. Blood Purif. 2017;44(1):30-1.

97 Cirstoveanu CG, Barascu I, Mc Kenzie Stancu S. Hemadsorption with Adult CytoSorb ${ }^{\circledR}$ in a Low Weight Pediatric Case. Case Rep Crit Care. 2017;2017:6987167.

98 Dhokia VD, Madhavan D, Austin A, Morris CG. Novel use of Cytosorb ${ }^{\mathrm{TM}}$ haemadsorption to provide biochemical control in liver impairment. J Intensive Care Soc. 2018;0:1-8.
99 Falthauser A, Kullmann F. Use of Hemoadsorption in a Case of Severe Hepatic Failure and Hyperbilirubinemia. Blood Purif. 2017; 44(2):98-9.

100 Tomescu DR, Olimpia Dima S, Ungureanu D, Popescu M, Tulbure D, Popescu I. First report of cytokine removal using CytoSorb $^{\circledR}$ in severe noninfectious inflammatory syndrome after liver transplantation. Int J Artif Organs. 2016 May;39(3): 136-40.

101 Houschyar KS, Nietzschmann I, Siemers F The Use of a Cytokine Adsorber (CytoSorb) in a Patient with Septic Shock and Multi-Organ Dysfunction (MODS) after a Severe Burn Injury. Handchir Mikrochir Plast Chir. 2017 Apr;49(2):123-6.

102 Houschyar KS, Rein S, Weissenberg K, Duscher D, Philipps HM, Nietzschmann I, et al. [Management of severe sepsis using a Cytokin-adsorber]. Unfallchirurg. 2018 Feb; 121(2):174-8.

103 Linden K, Scaravilli V, Kreyer SF, Belenkiy SM, Stewart IJ, Chung KK, et al. Evaluation of the Cytosorb ${ }^{\mathrm{TM}}$ Hemoadsorptive Column in a Pig Model of Severe Smoke and Burn Injury. Shock. 2015 Nov;44(5):48795.

104 Eid M, Fouquet O, Darreau C, Pierrot M, Kouatchet A, Mercat A, et al. Successfully treated necrotizing fasciitis using extracorporeal life support combined with hemoadsorption device and continuous renal replacement therapy. Int J Artif Organs. 2018 Mar;41(3):178-82.

105 Huber W, Algül H, Lahmer T, Mayr U, Lehmann M, Schmid RM, et al. Pancreatitis cytosorbents (CytoSorb) inflammatory cytokine removal: A Prospective Study (PACIFIC). Medicine (Baltimore). 2019 Jan;98(4): e13044. 